\title{
Контрдискурс по-русски, или sottisier à la russe: повесть Н. С. Лескова «Полунощники»
}

\author{
Н. С. НАЙДЕНОВА \\ Кафедра иностранных языков, Российский университет дружбы народов \\ ул. Миклухо-Маклая, д. 10/2, RU-117198 Москва \\ E-mail:nns1306@mail.ru
}

(Received: 25 January 2016; accepted: 30 March 2016)

\begin{abstract}
In this article, the author attempts to apply the concept of counter-discourse developed by R. Terdiman on the basis of research of the French literature of the 19th century to studying the language game in Полунощники [At Midnight] by N. Leskov. The discourse analysis of the novel reveals that the author's counter-discourse is built on the "sottisier" collected by the writer throughout his life, where commonplace utterances subjected to "re/citation" acquire a whole new meaning.
\end{abstract}

Keywords: Russian literature, 19th century, Nikolai Leskov, John of Kronstadt, counterdiscourse, sottisier

Контрдискурс - это термин, созданный американским исследователем P. Тердиманом на основе исследования французской литературы XIX века как эпохи появления голосов, стремящихся подорвать гегемонию доминирующего буржуазного дискурса (TERDIMAN 1985: 13). По мнению ученого, в основе проявления контрдискурса лежит стремление изменить и даже искоренить сложившееся в обществе мировидение, а также ставшие самоочевидными формы высказываний. Власть доминирующего дискурса заключается в кодах, через которые он регулирует понимание социальной действительности. Контрдискурсивные практики состоят в «раскодировке» механизмов подобного регулирования с целью подрыва их авторитета (TERDIMAN 1985: 149). Для этого необходима выработка таких нарративных стратегий, которые бы обеспечили саморазоблачение буржуазных практик, позволили бы «собрать фрагменты современного дискурса таким образом, чтобы обеспечить их очевидное для всех самоуничтожение», подвергнуть «ретекстуализации» то, что раньше считалось всеми общепринятым, что было отмечено печатью неоспоримой власти, чтобы обнажить его крайнюю интеллектуальную убогость (TERDIMAN 1985: 201).

Разработка теории контрдискурса Р. Тердимана в значительной мере основывается на исследовании произведений Г. Флобера «Бувар и Пекюше» и «Лексикон прописных истин» (FLAUBERT 1979). Неоконченный роман «Бувар и Пекюше» - история двух чиновников, переписывающих тексты из различных областей науки и создающих тем самым sottisier своей эпохи - сборник 
глупостей, банальностей и плоских мыслей. В романе писатель стремился «изрыгнуть на современников отвращение», которое они ему внушали (см. ФЛоБЕР 1984: 111). «История двух добряков, переписывающих своего рода критическую энциклопедию в форме фарса» (ИвАщЕнко 1956: 29), находит конкретное выражение в посмертном произведении Флобера - «Лексиконе прописных истин». Идея «Лексикона» зародилась у писателя еще в годы молодости, и запас выражений, содержавшихся в нем, он пополнял всю жизнь. «Лексикон» содержит свод «истин», которыми живет буржуа, представленных в гротескно-сатирическом плане.

Процесс создания контрдискурса Р. Тердиман подразделяет на две стадии. Первая состоит в том, чтобы скомпилировать высказывания современников и придать им текстовую оформленность. Первоначальную стадию исследователь именует стадией «хранилища глупостей» (the "sottisier" stage). Следуя примеру Г. Флобера, Р. Тердиман анализирует стратегию оформления фрагментов доминирующего дискурса таким образом, чтобы их несуразность проявилась сама по себе как «глубоко укоренившееся в их структуре означаемое» (deep-structural signified) (TERDIMAN 1984: 205-206).

Второй этап состоит в компиляции цитаций без атрибуции - создании корпуса анонимных высказываний, «всегда готового текста» (always-already constituted text). Эту стадию Р. Тердиман называет «стадией лексикона» (the “dictionary”stage) по аналогии с «Лексиконом прописных истин» Г. Флобера. На «стадии лексикона» происходит одновременное воспроизводство идеологических клише и их высмеивание. Иными словами, мы имеем дело с антиномией непроизвольного повторения высказываний «другого» и их намеренного порицания. Этот прием Р. Тердиман предлагает именовать ре/цитацией (re/citation) (TERDIMAN 1984: 210).

Ре/цитация превращает банальность, присущую клише и прописным истинам, в речевое событие. Самым эффективным способом для того, чтобы поставить под сомнение неоспоримость доминирующего идеологического дискурса, оказывается нарушение его внешней целостности за счет использования «искаженных высказываний» (corrupted utterances), каждое из которых показывает, «как не надо писать или говорить» (TERDIMAN 1984: 212).

В контрдискурсивных практиках, возведенных в абсолют, прослеживается «примитивная воля к ниспровержению всего» (TERDIMAN 1984: 331), конструирование текста «от противного», вызванное страхом того, что обыденный языковой узус «сведет на нет» все стремления к инаковости. Контрдискурс выражается в стремлении нарушить существующую языковую норму в максимально возможном объеме, но без полного отрыва от нее, т. е. при условии, что создаваемый текст будет понят читателем.

Наиболее характерной тональностью контрдискурса является комическое, обретающее различные обертоны, в числе которых - едкая ирония, которую Р. Тердиман именует «нулевой степенью контрдискурса» (TERDIMAN 1984: 76-77). Контрдискурс задействует широкий спектр новаторских техник. Изучение произведений русских писателей в подобном ракурсе еще не 
предпринималось, и для исследования стратегий выработки контрдискурса нами было выбрано творчество Н. С. Лескова, где в концентрированном виде представлена языковая игра, с помощью которой реализуется идейноэстетический замысел автора. Материалом для анализа послужила опубликованная в 1891 г. повесть «Полунощники» - одно из загадочных произведений писателя, в котором контрдискурс создается исключительно за счет языковых средств.

Н. С. Лесков, вошедший в литературу в возрасте около тридцати лет, по долгу службы много путешествовал по всей России. В течение всего этого времени он тщательно наблюдал за речью представителей различных сословий. Сам писатель отмечал следующее: «язык, которым написаны многие страницы моих работ, сочинен не мною, а подслушан у мужика, у полуинтеллигента, у краснобаев, у юродивых и святош. Ведь я собирал его много лет по словечкам, по пословицам и отдельным выражениям, схваченным на лету в толпе, на барках, в рекрутских присутствиях и монастырях... Я внимательно и много лет прислушивался к выговору и произношению русских людей на разных ступенях их социального положения. Они все говорят у меня посвоему, а не по-литературному» (ФАРЕсов 1904: 273-274).

Этап постепенного накопления словечек «полуинтеллигентов и краснобаев» представляет собой аналог стадии создания «хранилища глупостей». Собранный по крупицам материал писатель подвергает ре/цитации и использует для написания остро сатирических произведений, к которым относится и повесть «Полунощники». «Я... не хочу нравиться публике... Я хочу бичевать ее и мучить» (ФАРЕСов 1904: 382), - заявляет Н. С. Лесков о своем творчестве 1890-х гг.

Язык «Полунощников» вызвал шквал критики, отмечавшей его «чрезмерную деланность», «мудреные и в общем уродливые слова» (Волынский 1923), «невероятную причудливость и исковерканность» (СлЕПцов 1892). Столь отрицательная рецепция в конце XIX века свидетельствует о том, что писатель в известной мере опередил свое время, задействовав языковые стратегии, которые получат широкое распространение лишь в середине XX - начале XXI веков. Как отмечает Б. С. Дыханова, новыми эстетическими открытиями Лесков предваряет появление русского модерна (ДыхАновА 2004).

Повесть «Полунощники» представляет собой пересказ подслушанного разговора между богатой купчихой Аичкой и ее оборотистой компаньонкой Марьей Мартыновной. Диалог происходит в так называемой «ажидации» петербуржской гостинице, в которой останавливаются постояльцы, ищущие встречи с неким «духовным лицом», прототипом которого выступает о. Иоанн Кронштадтский. ${ }^{1}$ Марья Мартыновна, ранее бывшая приживалкой в купеческом доме, рассказывает историю о том, как ей удалось привезти туда кронштадтского пастыря для вразумления юной Клавдии, не желающей жить

\footnotetext{
${ }^{1}$ Протоиерей Иван Ильич Сергиев, в 1990 г. канонизированный Русской Православной Церковью как Святой Праведный Иоанн Кронштадтский.
} 
подобно своему окружению, полностью отрицающей обрядовую сторону церковной жизни и руководствующуюся исключительно Евангелием. ${ }^{2}$

Речь Марьи Мартыновны насыщена лексемами из «варварского языка», воссозданного писателем на основании «quasi-ученой литературы» (ФАРЕсов 1904: 275). При этом в речи рассказчицы просторечия (жох, шебаршить, на фортепианах, вскорях, ихний, ужасти, к завтрему, откудова, нутреной карман, головою замахает, запрег, снилося) сочетаются с книжной лексикой (вещче зеницы, плечом воздвигнул, все трое ниспроверглись, пещчись о благе). Как отмечает В. В. Леденева, в творчестве Лескова коннотации вступают в противоречие со стилистическим статусом слова, сложившимся в узусе пейоративные у единиц книжной лексики и мелиоративные у разговорных (ЛЕДЕНЕВА 2000: 440-441). Подобный контраст делает еще более гротескным нагромождение «ученых» фраз из авторского sottisier, девальвируя их и низводя их до уровня просторечий.

Значительное количество авторских неологизмов создается с помощью аффиксов, свойственных научному стилю речи: назидащия вместо «назидание», катастрофия вместо «катастрофа», интригантус вместо «интриган». Используются кальки (вездеприсутствие от фр. omniprésence) и заимствования в искаженной форме, в основном из французского языка: грандеву (от фр. rendez-vous 'встреча'), политический компот (от фр. complot 'заговор'), антруи (от фр. en trois 'втроем'), мете ву пляс (от фр. mettez-vous à vos places 'рассаживайтесь по местам'), капишон (от фр. cornichon 'корнишон'), у е ля хам (от фр. où est la femme 'где женщина').

Зачастую русские лексемы объединяются с помощью французского $a$-ля или немецкого фон-: живот «а-ля-пузе́», одет а-ля-морда, фон-горская коза. Сатирический эффект достигается за счет использования неологизмов, основывающихся на фонетической аналогии. Так, например, в речи француженок на танцевальном вечере рассказчице слышатся такие новообразования, как mpe-шепете́, тре-журавле́, nacé u nерепасе́. Не желая платить по счету, один из героев повести сует ресторатору под нос кукиш со словами «Это хабензи гевидел?» (164), ${ }^{3}$ что представляет собой искажение немецкой фразы Haben Sie gesehen? 'Вы видели это?', а лексема гевидел образована за счет присоединения немецкого префикса ge- к русскому глаголу «видел». В дальнейшем Марья Мартыновна не раз использует этот неологизм в различных видо-временных формах (гевидишь, хабензи увидишь).

Речь рассказчицы насыщена плеоназмами самого разного характера: «слишком больше, чем надобно» (142); «дом был самый очень вылаюшийся» (136); «это тоже необходимо надобно» (156). Велико число морфемных повторов: «крыши крыть» (166); «с ней разводов разводить нечего» (175); «горда,

\footnotetext{
2 По мнению ряда критиков и исследователей, Клавдия отражает взгляды последователей толстовства (см. АРХИМАНДРИТ АНТОНИЙ 1892, ИльИНСКАЯ 2010, MCLEAN 1977).

${ }^{3}$ Источником цитат из произведения Н. С. Лескова является книга: ЛЕсков Н. С. Полунощники. Пейзаж и жанр. В кн.: Собрание сочинений в 11 томах. Т. 9. Москва, 1958. 117-217. 
как самый горделивый зверь» (203); «заказы заказывают» (207); «забыл, про что он позабыл» (207); «да как же вы не верите, когда я вас уверяю» (213).

Писатель часто намеренно не соблюдает принципы лексической и семантической сочетаемости: «и вдруг ему увертюра московского воспоминания в лоб вступила» (139); «стекло зазвонило вдребезги» (179). Отмечены случаи нарушения реализации глагольных валентностей: «заболела в черной оспе» (151); «дело до... рубкопашного боя угрожается» (164); «она умом всюду вертится» (153); «вслед за нею достигнуть» (138); и использования непродуктивных типов многозначности глагола: «ты его бунтуешь» (208).

Двуличность рассказчицы выявляется за счет использования в одной фразе двух противоположных по значению лексем: «Да, если только в этом, то это, конечно, благословенный закон супружества, и в таком случае Бог тебе наверно поможет!» (217).

С особой виртуозностью Н. С. Лесков вводит в текст повествования лингвистические термины, где они обретают новое, совершенно иное для них значение и служат для создания комического эффекта, придавая псевдонаучный характер словам рассказчицы. Еще в самом начале Марья Мартыновна с гордостью заявляет, что она «говорит грамматически» (132). Этот факт находит подтверждение не только в ее смелом языковом новаторстве, но и в регулярном использовании таких терминов, как ударение, наклонение, междометие, падеж. Так, лексема ударение подвергается переосмыслению, основанием для которого служат, вероятно, глаголы «приударить» и «удариться во что-либо»:

Ее имя было Клотильда, но мы Крутильдой ее называли, потому что она все, бывало, не прямо, а крутит, пока какое-то особенное ударение ко всем его чувствам сделает... (138).

Как только напосудится, так и Крутильду забыл, и сейчас новое ударение к дамской компании... (140).

Термин наклонение служит для описания неясности, нерешительности: «замялась в неопределенном наклонении» (140); «множественный разговор в неопределенном наклонении» (159); «держалась наклонения неопределенного» (166); или наказания: «таково же им и от Бога наклонение» (207). Междометие используется в значении «вопрос, дело»: «и так и пошло с ней с этих пор во всех междометиях» (144). Родительный падеж используется в качестве эвфемизма при признании Марьи Мартыновны в клевете на хозяйскую дочь:

- Значит, всего-навсего и было, что раз один поцеловала?

- Так она сказала.

- Ну, а это-то... про что она раньше-то еще сознавалась?

- Что такое?

- Ну вот, что вы рассказывали...

- Ах, это про родительный в неопределенном наклонении? 
- Да.

- А это так и осталось в неопределенном наклонении (210).

Стремление к манерности речи находит выражение и на уровне синтаксиса в использовании громоздких синтаксических конструкций, утяжеляющих слог рассказчицы:

...старухи пишут куриляпкою и своего руки подчерка совестятся, а у меня mе, ша и ша, те всегда в один вид сливаются, и в другой раз смысла не выходит (158).

Был дом выдающийся в великолепии, а теперь одна катастрофия за другою следует, и жительство их спускается до самого обыкновенного положения (207).

Многочисленны случаи нетипичного порядка слов с нарушением грамматической сочетаемости:

Вы, Клавдинька, хоть для дня ангела маменькиного нынче эту заунывность можно бы оставить вспоминать... (148).

И это мне извозчик говорил очень полезное и хорошо... (168).

Контрдискурсивная линия, направленная в адрес малообразованных людей, стремящихся изъясняться «ученым» языком, реализуется на всех языковых уровнях за счет использования гетерогенного набора лексических единиц из «хранилища» писателя, относящихся к самым разным стилевым регистрам. Комический эффект достигается за счет использования авторских неологизмов, контаминированных лексем и синтаксических конструкций. Так автор поражает оппонентов, в адрес которых направлен контрдискурс, их же оружием. Марья Мартыновна уподобляется флоберовским переписчикам, по мнению которых «страница должна быть исписана. Все равно: добро и зло, фарс и возвышенное, прекрасное и уродливое...» (FLAUBERT 1966: 57).

Вторая стадия выработки контрдискурса, подразумевающая, согласно Р. Тердиману использование стратегии ре/цитации, реализуется автором благодаря жанровой специфики повести. Повесть носит подзаголовок «пейзаж и жанр». Как отмечает Д. С. Лихачев, эту литературную форму Лесков создает для полного самоустранения: «Автор даже не прячется здесь за спины своих рассказчиков или корреспондентов, со слов которых он якобы передает события, как в других своих произведениях, - он вообще отсутствует [курсив - Н. Н.], предлагая читателю как бы стенографическую запись разговоров, происходящих в... гостинице... По этим разговорам читатель сам должен судить о характере и нравственном облике разговаривающих и о тех событиях и жизненных ситуациях, которые за этими разговорами постепенно обнаруживаются перед читателем» (ЛихАчев 1988: 140-141).

Именно в этом состоит особенность лесковского сказа, когда «чужая словесная манера используется автором как точка зрения, как позиция, необходимая ему для ведения рассказа» (БАхтин 2000: 89), представляющая собой 
платформу для создания контрдискурса. О личности и жизненном пути Марьи Мартыновны мы узнаем исключительно из ее же собственных слов. И именно такая структура позволяет автору в полной мере воспользоваться стратегией ре/цитации. Отдельные комментарии Марьи Мартыновны свидетельствуют о том, что она неплохо знакома с церковными обрядами и Священной историей. Так, ее удивляет неурочное проведение всенощного бдения: «Не может быть... завтра нет никакого выдающегося праздника» (170). Первым делом в храме она стремится поклониться «боготворной иконе» (170). Она довольно подробно пересказывает своей хозяйке фрагменты ветхозаветной истории про Исава и Иакова (171), а «ажидацию» сравнивает с горой Фавор (216). Хотя это и не говорится напрямую, она регулярно участвует в богослужениях. Об этом свидетельствует тот факт, что ее речь насыщена цитатами из литургических текстов и Священного Писания: «ну, думаю, с миром изыдем» ${ }^{4}(165)$; «суетная и ложная» ${ }^{5}(150)$; «я отправилась творить волю пославшего» ${ }^{6}(167)$; «он вошел... и сказал: „Мир всем“»» ${ }^{7}(186)$; «по вере вашей и будет вам» ${ }^{8}(189)$.

В яркое противоречие с этими фактами вступают высказывания Марьи Мартыновны, отражающие ее «житейскую мудрость», но никак не соответствующие евангельским заповедям. Так, она заявляет, что «не во все же веришь, о чем утверждают духовные, но не препятствуешь им, чтобы другие им верили» (189), а чтобы угодить своей покровительнице, готова сжить со свету ее непокорного жениха. Использование двух прямо противоположных стратегий в речи персонажа изнутри подрывает ее цельность, вскрывая те отрицательные черты, против которых направлен контрдискурс писателя. Создавая образ персонажа, автор совершенно не прибегает к описанию, но строит его исключительно за счет стратегии ре/цитации.

Кроме того, библеизмы служат основой и для образования контаминированных лексем: вифлиемция от «Вифлием» и «инфлюэнца», кутинья от «кутить», «кутерьма» и «ектения»); каламбуров: «жена-переносица» (132); «идет глас выпивающий... уготовьте путь ему в пустыне» (174); и соседствуют с просторечиями: «Про что это здесь настрочено это к Корифеям послание...» (159). Подобная карнавализация языка оказывается для писателя одной из магистральных стратегий выработки контрдискурса, реализуемого благодаря достижению «свободы от всех речевых норм, от всей установленной языковой иерархии», когда утрачивают «свою силу разделения высокого и низкого, запретного и дозволенного, священного и профанного в языке» (БАХТин 1990: 521).

Творческой трансформации подвергаются цитаты из работ украинского религиозного философа Г. Сковороды о том, что «цыпленок зачинается,

\footnotetext{
${ }^{4}$ Возглас священника на Литургии.

${ }^{5} \mathrm{Cp}$. «Чтущие суетных и ложных богов оставили Милосердаго своего» (Ион. 2:9).

${ }^{6}$ Cр. «Моя пища есть творить волю Пославшего Меня» (Ин. 4:34).

${ }^{7}$ Благословение священника на Литургии.

${ }^{8}$ Ср. «по вере вашей да будет вам» (Мф. 9:29).
} 
когда портится яйцо» (СковородА 1: 23) и о пути благочестивого сердца «между высыпанными курганами буйного безбожия и между подлыми болотами рабострастного суеверия» (СковородА 2: 8). Загадочному Моисею Картонычу, выступающему в качестве посредника при организации встреч с известным пастырем, дается следующая характеристика: «...он в болоте на цаплиных яйцах сидит - живых журавлей выводит» (169).

Переходя от цитации к ре/цитации, автор создает яркий образ персонажей, процветающих за счет искаженных представлений окружающих их людей о вере. Например, традиционное напутствие «с Богом» вкладывается в уста мужика «аплетического сложения» из «артели со старостой», которые «работать не охотники», и занимаются тем, что за мзду прокладывают путь «духовному лицу» к определенной карете: «Я подманила этого промыслителя и дала ему гривенник, но он малый смирный - недоволен моей гривной, а просит рубль. Дала рубль - он к нашей карете ход и открыл, понапер, понапер и впихнул его в самые дверцы и крикнул: „С богом!“” (183).

Формула благословения, которую, в частности, использовал Св. Серафим Саровский при прощании («Грядите с Богом!»), звучит совершенно неуместно в данном контексте и становится частью «лексикона несуразностей». К нему же можно отнести и восклицание Аички «Ах, это люблю - пророчества!» ${ }^{9}$ (135), и сетования Николая Ивановича, дяди главной героини, о том, что он «должен за свою веру в тюрьме сидеть», так как пустил «блеярдный шар в лоб» профессору, заявившему, что «его ангел Никола» отсутствовал на Вселенском соборе 325 г. и потому не мог «посреди собора Ария по щеке хлопнуть» (156-157).

Диалоги между идеологическими противниками в повести построены по принципу повтора. Например, в основе разговора между Клавдинькой и священником лежит синтаксический параллелизм:

- Нехорошо, барышня, нехорошо, вы в заблуждении.

А она ему бряк наотрез:

- Да, - говорит, - благодарю вас, благодарю, вы правы... (144-145).

С помощью синтаксических средств писатель подчеркивает внешнюю смиренность девушки, воплощающую толстовский принцип «непротивления злу насилием». В то же время, антитеза «вы в заблуждении» - «вы правы» говорит о непримиримом несогласии героини с мнением собеседника, реализуемом в виде бинарной оппозиции.

Разговор Клавдиньки с Марьей Мартыновной построен на основании лексико-синтаксического повтора:

- ...Вы о доброте как должно не понимаете.

- Ну, прекрасно, я о доброте не понимаю... Разве это мысли́мо или честнымми правилами требуется?

${ }^{9}$ Ср. «...род лукавый и прелюбодейный ищет знамения» (Мф. 12:39). 
А она, вообрази, с улыбкою отвечает:

- Да, это мыслимо и честными правилами требуется! (149).

Практически полный повтор фразы собеседника, сказанной с оттенком иронии и недоверия, подчеркивает намерение Клавдиньки казаться незлобивой по отношению к Марье Мартыновне, которую та считает «несчастной».

Клавдия настолько часто прибегает к данной стратегии, напоминающей технику «отзеркаливания» в нейролингвистическом программировании, что это замечает даже Марья Мартыновна, «к наукам никакой памяти не имеющая»:

Я говорю:

- Клавдия Родионовна, бросьте свои трелюзии - утешьте мамашу-то, выйдите, пожалуйста.

А она мне это же мое последнее слово и отвечает:

- Выйдите, пожалуйста! (188).

Необходимо отметить, что такие стилистические фигуры, как повторы и различные виды симметрии, особенно присущи ветхозаветным текстам (ЯкоБСон 1987, ДЕсницкий 2007, КАРСОН 2000). Наполняя структуру ветхозаветного текста ${ }^{10}$ новым лексико-семантическим содержанием, писатель тем самым призывает современников отказаться от отжившего свой век, наполненного ханжеством и лицемерием «темного царства», в которое не проникает свет нового Евангелия, и позволить в нем дышать «бодрому духу Клавдиньки, дающему ресурс к жизни во всяком положении, в котором высшей воле угодно усовершать в борьбе со тьмою все рожденное от света» (217).

Итак, проведенный анализ показал, что для создания контрдискурса писатель использует широкий арсенал накопленных в его sottisier несуразностей. Для их ввода в ткань повествования автор привлекает множество приемов, состоящих в гротескном сочетании псевдонаучных лексем и просторечий, смешении сакрального и бытового, создании авторских неологизмов, плеонастическом словоупотреблении, нарушении правил коллокации, переосмыслении терминов с точки зрения «народной этимологии». Чтобы обнажить духовную и интеллектуальную пустоту говорящего, автор прибегает к ре/цитации прецедентных текстов (в частности, Священного Писания) персонажем, чье мировоззрение и поступки оказываются несовместимы с христианством, а также искажению богословской лексики. В синтаксическом плане доминируют фигуры антитетического и синонимического параллелизма. Смешение стилистических регистров, контаминированные конструкции, наложение профанного дискурса на синтаксическую структуру библейского текста позволяют писателю создать палимпсест, окончательная расшифровка которого еще впереди.

${ }^{10}$ В этой связи необходимо упомянуть статью Б. С. Дыхановой, в которой прослеживаются параллели между помещением «ажидации» и ветхозаветным храмом (ДыХАНОВА 2004). 


\section{Литература}

АРХимАндРит Антоний 1892 = АРХимАндРит Антоний (Храповицкий): Знамение времени («Полунощники». Повесть Н. Лескова). Богословский вестник 1892. Т. 1. № 2. 415-419.

БАХТИН 1990 = БАХТИн М. М. Творчество Франсуа Рабле и народная культура средневековья и Ренессанса. Москва, 1990.

БАХТИн 2000 = БАХТин М. М. Собрание сочинений в 7 томах. Т. 2. Москва, 2000.

Волынский 1923 = Волынский А. С. Н. С. Лесков. Критический очерк. Санкт-Петербург, 1923.

ДЕсницкий 2007 = ДЕсницкий А. С. Поэтика библейского параллелизма. Москва, 2007.

ДыхАНОВА 2004 = ДыхАНОВА Б. С. «Пейзаж и жанр» лесковских «Полунощников»: живопись с натуры или герменевтика образов? Русская литература 2004/3: 1628.

ИВАЩЕНКО 1956 = ИвАЩЕНКО А. Ф. Гюстав ФЛобер. Предисловие. В кН.: ФЛОБЕР Г. Собрание сочинений в 5 томах. Т. 1. Москва, 1956. 3-36.

ИльИНСКАЯ $2010=$ ИльИНСКАЯ Т. Б. РУсское разноверие в творчестве Н. С. Лескова. Санкт-Петербург, 2010.

КАРСОН 2000 = КАРСОН Д. Новый Библейский Комментарий в 3 томах. Т. 2. Ветхий Завет. Санкт-Петербург, 2000.

ЛЕДЕНевА 2000 = ЛЕДЕНЕВА В. В. Особенности идиолекта Н. С. Лескова. Средства номинаџии и предикаџии. Диссертация доктора филологических наук. Москва, 2000.

ЛиХАЧЕВ 1988 = ЛиХАЧЕВ Д. С. Лесков и русская литература. Москва, 1988.

СковородА = СковоРодА Г. С. Сочинения в 2 томах. Т. 1-2. Москва, 1973.

СлеПцОв 1892 = СлЕПцОв А. А. Литература 1891 года. Русское богатство 1 (1892): $105-124$.

ФАРЕСОВ 1904 = ФАРЕСОВ А. И. Против течений. Н. С. Лесков. Его жизнь, сочинения, полемика и воспоминания о нем. С редким портретом. Санкт-Петербург, 1904.

ФЛОБЕР 1984 = ФЛОБЕР Г. О литературе, искусстве, писательском труде: письма, статьи. Т. 2. Москва, 1984.

ЯкоБсон 1987 = ЯкоБсон Р. О. Работы по поэтике. Москва, 1987.

Flaubert 1966 = Flaubert Gustave: Le Second Volume de Bouvard et Pécuchet, établi et présenté par Geneviève Bollème. Paris, 1966.

Flaubert 1979 = Gustave Flaubert: Bouvard et Pécuchet. Avec un choix des scénarios, du Sottisier, l'Album de la Marquise et Le Dictionnaire des idées reçues. Paris, 1979.

MCLEAN 1977 = MCLEAN Hugh: Nikolai Leskov. The Man and His Art. Cambridge, 1977.

TERDIMAN 1985 = TERDIMAN Richard: Discourse/Counter-Discourse. The Theory and Practice of Symbolic Resistance in Nineteenth-Century France. Ithaca-London, 1985. 